\title{
Sticking it on Plastic: Credit Card Finance and Small and Medium Sized Enterprises in the UK
}

\author{
Ross Brown ${ }^{*}$ \\ Centre for Responsible Banking \& Finance, School of Management, \\ University of St Andrews \\ Ross.Brown@st-andrews.ac.uk \\ Jose Liñares Zegarra \\ Essex Business School, University of Essex \\ jmlina@essex.ac.uk \\ John O.S. Wilson \\ Centre for Responsible Banking \& Finance, School of Management, \\ University of St Andrews \\ jsw7@st-andrews.ac.uk
}

\section{Acknowledgements}

The authors are very grateful to Ivan Turok, Tomasz Mickiewicz and the guest editors of this Special Issue for their feedback and assistance during the review process. We also wish to thank Neil Lee for his kind permission to use the map depicted in Figure 1. The authors are also very grateful for the extremely constructive comments from the three referees on earlier versions of the manuscript. The usual disclaimer applies.

\footnotetext{
* Corresponding author: Ross Brown, Centre for Responsible Banking \& Finance, School of Management, Gateway Building, University of St Andrews, St Andrews, Fife, KY16 9RJ, UK.
} 


\title{
Sticking it on Plastic: Credit Card Finance and Small and Medium Sized Enterprises in the UK
}

\begin{abstract}
This paper investigates the role of credit card financing in UK small and medium sized enterprises (SMEs) and how this varies by location and business orientation. Using a large scale dataset of UK SMEs, the results of a regression based analysis suggest that firms located in peripheral geographic areas have greater usage of credit cards relative to counterparts located in 'core' locations. Innovative, growth, and export-oriented SMEs are also more inclined to use credit card financing. Moreover, SMEs that use credit cards as a form of improvised financial 'bootstrapping' are more likely to seek additional funding sources in the future.
\end{abstract}

Keywords: Finance, SMEs, credit cards, bootstrapping, peripheral locations, thin markets 


\section{Introduction}

This paper investigates the use of credit card financing by UK small and medium sized enterprises (SMEs) and how this varies by business orientation and location. While extant research has sought to understand the dynamics of entrepreneurial finance such as venture capital, business angels and crowdfunding (Brown et al, 2017; Nightingale et al, 2009), credit card finance has received much less attention (Blanchflower and Evans, 2004). This is somewhat surprising given that the proportion of SMEs using credit card financing has increased steadily since the global financial crisis (Mach and Wolken, 2006; Scott, 2009; Wille et al, 2017). ${ }^{1}$

In the UK, the use of credit card financing by SMEs is commonplace (BIS, 2016), with overall reported use (over the period 2013, Quarter 3 to 2015, Quarter 4) fluctuating between $14 \%$ and $20 \%$. In Quarter 4 of 2015, use of credit cards as a source of funding for SMEs $(17.1 \%)$ was similar to the use of bank overdrafts $(17.4 \%)$, and exceeded the use of bank loans and commercial mortgages $(7.7 \%){ }^{2}$ UK SMEs have an average credit card debt of $£ 30,000$ (Hesse, 2012). Moreover, credit cards have the second highest success rate for SMEs applying for finance, with a quicker application process than a conventional bank loan (Owen et al, 2016).

Credit cards provide flexible financing, allowing SMEs to adjust expenditure to fit patterns of cash flow. Evidence suggests that entrepreneurs can circumvent credit rationing via credit card financing (Mach and Wolken, 2006). However, credit cards are expensive relative to other forms of finance, especially for firms that do not pay off outstanding balances at the end of each month. ${ }^{3}$ Prior evidence suggests that fast-growing opaque firms with limited collateral are therefore more likely to use credit card financing (Blanchflower and Evans, 2004). However, credit card borrowing may attract riskier borrowers willing to

\footnotetext{
${ }^{1}$ Examples abound of entrepreneurial companies, such as Google and Halo Top, who have used credit card financing (Deutsche Bank, 2009; Financial Times 2018).

${ }^{2}$ This is perhaps unsurprising given that the UK is the largest credit card market in Europe, accounting for over $70 \%$ of all credit cards in the EU (UK Cards Association, 2014). Indeed, the UK credit card market has expanded significantly over the last two decades with 34 new entrants between 2000-2010 most of whom are existing UK and foreign-owned banks (BIS, 2016). Therefore, large banks are inadvertently the main mechanism through which SMEs obtain unsecured credit card lending.

${ }^{3}$ In August 2017, the typical APR on a Barclays small business loan was 9\% approximately while the APR on a personal or business credit card is typically $19 \%$.
} 
pay high interest rates resulting in 'shakier firms hooked on plastic' (Deutsche Bank, 2009, p.12).

Evidence regarding geographical variations in credit card financing remain scant. Given that access to finance is spatially uneven across the UK (Lee and Brown, 2017), credit constrained SMEs in more peripheral areas (that are spatially remote and potentially inaccessible) may be more pre-disposed to using credit cards to finance day-to-day activities and longer term growth (due to a lack of suitable alternatives). Often peripheral locations are characterised by a lack of venture capital and business angel financing (so-called thin markets) which are common sources of finance for risky and innovative firms (Nightingale et al, 2009).

In this paper, we examine for the first time the use of credit cards by UK SMEs from a spatial perspective. We use data collected from the UK SME Finance Monitor. We employ a probit model to investigate the probability of a SME using credit card financing, while taking explicit account of location. Our outcome variables are binary and capture SME use of credit cards, and whether an SME is likely to apply for more external finance in the next three months. Our key independent variable is an indicator variable, which captures whether a SME is located in a 'core' or 'peripheral' geographic location. We also classify SMEs based on their respective business orientation toward innovation, growth and exports. A series of covariates are also included to account for differences in firm size, profitability, age, legal form, firm risk, extent of strategic planning, and the gender and ethnicity of main owner.

By way of preview, the results of our empirical analysis suggest that SMEs located in peripheral geographic areas have greater use of credit cards than counterparts located in core locations. Innovative, growth and export-oriented firms located in peripheral geographic locations are more likely to use credit card financing than counterparts located in core geographic areas. We also find that innovative, growth and export-oriented SMEs located in peripheral geographic areas relying on credit card financing are likely to seek other types of financing in the future. Overall, the results of this study not only provide insights as to the level and geographic variation in SME credit card financing, but also have relevance for government agencies and policymakers concerned with improving access to funding for SMEs. The remainder of the paper is structured as follows. Section 2 reviews relevant literature and presents testable hypotheses. In section 3 we present the data set utilised and outline the estimable models. Section 4 presents the results while Section 5 concludes. 


\section{Relevant Literature and Hypotheses}

In theory, the use of credit cards should be unattractive to credit-constrained SMEs due to the high levels of interest charged by these lenders. Under the pecking order theory of funding preferences (Myers and Majluf, 1984), SMEs are expected to first seek recourse to friends and family for finance, and only if this is unavailable then turn to bank debt. However, informational opacity and insufficient collateral ensure that SMEs encounter restrictions when attempting to secure bank loans and overdrafts (Berger and Udell, 1998). This may lead credit-constrained SMEs to seek more expensive alternative forms of finance such as credit cards.

Two strands of empirical literature are pertinent to the current investigation. The first draws on large scale national surveys (mostly in the UK and US) to explore the level credit card use by SMEs. Blanchflower and Evans (2004), for example, find that $46 \%$ of SME owners use personal credit cards to finance business activities with another 34\% of SMEs using business credit cards. The second is the entrepreneurial bootstrapping literature (Ebben and Johnston, 2006). ${ }^{4}$ Evidence emerging from this literature suggests that some $85 \%$ to $90 \%$ of SMEs sampled utilise some form of bootstrapping (Harrison et al, 2004). Bootstrapping through the use of credit cards is an easy way to obtain financing without pledging collateral.

To our knowledge, no research to date has examined specifically spatial variations in the use of credit cards by SMEs. This seems an important omission especially as traditional sources of bank and equity finance are harder to obtain by SMEs located in remote geographical areas (Zhao and Jones-Evans, 2017). Accordingly, prior research has identified an urgent need to examine 'the entire range of funding institutions constituting thin markets' (Lee and Brown, 2017, p.255). As a consequence, it would seem likely that credit constrained SMEs located in peripheral geographic areas would be more inclined to use alternative sources of finance. In this context we state the following hypothesis:

H1: SMEs located in peripheral locations have greater usage of credit cards than counterparts located in core locations.

\footnotetext{
${ }^{4}$ Examples of bootstrapping include renting rather than buying equipment, withholding managerial salaries and using personal credit cards to finance business operations.
} 
Given the importance of informational opacity in lending decisions, growth-oriented and innovative SMEs are often the most credit constrained firms (Lee et al, 2015). ${ }^{5}$ While less research has examined the correlation between financing constraints and export intensity, evidence suggests that many growth-oriented firms aim to grow via international expansion (Mason and Brown, 2013). As a consequence, we would expect that more informationally opaque SMEs (in other words those that are growth-oriented, innovative and export-oriented) are more likely to use alternative sources of finance. In this context we state the following hypothesis:

H2: Growth, innovative, and export-oriented SMEs have a greater use of credit cards than non-growth, non-innovative and non-export-oriented counterparts.

Given the lack of collateral and high levels of opacity, financing constraints are likely to be more prevalent for growth-oriented and innovative SMEs located in peripheral locations (Lee and Brown, 2017). As a consequence, we would expect that the relationship between being located in a peripheral location and credit card use to be affected by the business orientation of a SME. We explore this possibility by introducing to our empirical model (outlined in Section 3.2) an interaction term between SME location and business orientation. In doing so we are able to test empirically the differential impact of SME location on the probability of using credit cards, among groups of firms with a similar business orientation. ${ }^{\mathbf{6}}$

The use of credit cards also has implications for the longer-term capital structure of SMEs (Robb and Robinson, 2014). Prior entrepreneurial bootstrapping literature portrays credit cards as a key stop-gap financing measure. However, this literature fails to explain how financing evolves over time. What happens post-bootstrapping is important given that eventually growth-oriented SMEs are likely to seek external finance to fund their expansion (Cosh et al, 2009). This aligns with prior evidence which emphasises interconnections between insider and external sources of finance (Berger and Udell, 1998). In this context we state the following hypotheses:

H3. SMEs using credit cards have a stronger propensity to apply for further external finance compared to counterparts that are non-credit card users.

\footnotetext{
${ }^{5}$ For theoretical discussions on borrower opacity and business lending see Udell (2015).

${ }^{6} \mathrm{We}$ thank an anonymous referee for suggesting a further exploration of these interactions.
} 
The acceptance of H3 would suggest that credit card finance is used as a springboard to obtaining longer-term external finance. In this context, it could be also argued that location and business orientation are potential factors affecting this relationship. We investigate this possibility by testing whether $\mathrm{H} 3$ is affected by both SME location and business orientation.

\section{Data and Methods}

\subsection{Data and Variables}

Our data is sourced from the UK SME Finance Monitor, which is a nationally representative sample of SMEs in the UK covering the period 2013 - Quarter 3 through 2015 - Quarter 4 (BDRC, 2016). This dataset comprises approximately 50,000 observations, compiled from around 5,000 interviews with SMEs in each quarter. The actual sample size varies from quarter to quarter, depending upon the willingness of SMEs to complete the survey. The survey spans nine industry categories (agriculture and hunting; manufacturing; construction; wholesale, retail; hotels and restaurants; transport; real estate; health social work and other sectors) and 12 economic regions (at the Nomenclature of Territorial Units for Statistics, NUTS 1 level).

In order to qualify for inclusion in the survey, SMEs must satisfy (in addition to size, sector and locational requirements) the following criteria. First, an SME should be independent (with equity ownership by another company that does not exceed 50\%). Second, an SME should not operate as a social enterprise or a not-for-profit organisation. Third, an SME should have an annual turnover of less than $£ 25$ million. The main respondent is the person in charge of managing finances for each SME.

The survey includes detailed information relating to prior borrowing, future intentions to borrow, and the credit rating of SMEs. Financial information and information on sentiment relating to current and future financing is also reported. One of the main advantages of the survey is that it contains spatial information at postcode level. This allows us to identify the exact location of SMEs, and differentiate between those located in peripheral geographic areas and those located in more accessible areas in terms of the combined time to travel by road, rail and air (Lee and Brown, 2017).

Table 1 provides summary statistics and variable definitions. Our key dependent variables capture SME use of credit cards and whether the SME is 'very likely' or 'fairly likely' to apply for more external finance in the next three months. Both variables are binary 
and time varying. On average $15.8 \%$ of our sample of SMEs use credit cards, while $7 \%$ are planning to apply for additional funding in the near future.

Our key independent variable is an indicator variable which captures whether a SME is located in a 'core' or 'peripheral' location. In order to construct this variable, we first identify the potential geographical accessibility of all UK regions (at the NUTS 3 level) using the ESPON accessibility index. This is based on two elements, namely: the population of NUTS 3 regions and the effort in time to reach them for rail, road and air (ESPON 2009). For the present study, we rely on a multimodal version of the index where the accessibility by road, rail and air is integrated into one indicator, which expresses the combined effects of these modes of transport for each NUTS 3 region. The multimodal accessibility index is therefore calculated as a weighted average of the total population of other NUTS 3 European regions, using the combined travel time by road, rail and air networks as a weighting factor. ${ }^{7}$ This accessibility index describes how easily individuals in one NUTS 3 region can travel to individuals located in other regions within Europe and border areas (rather than just within the UK).

Given that the UK SME Finance Monitor contains data at postcode area level and the ESPON accessibility index is defined at NUTS region level, we follow the methodology suggested by Lee and Brown (2017) and compute a weighted average accessibility index for each postcode area, where the weighting factor is defined as the ratio of postcodes units in a given area to the total number of postcodes (as a proxy for population size) across each area. ${ }^{8}$ Peripheral locations are then defined as those in the lowest $10 \%$ in terms of geographical accessibility according to travel time using road, rail and air in the UK. Areas near London tend to score highly, as do Manchester and Birmingham (which combine air accessibility with good rail and road links). The rationale for adopting this definition is that most of the main UK banks have their headquarters located in highly accessible major urban agglomerations such as London. Prior evidence suggests that closer proximity between bank branches (where information on SMEs is collected) and bank headquarters (where the

\footnotetext{
${ }^{7}$ The accessibility index uses standardized values relative to the EU-27 average with 100 being the average level of accessibility. Accessibility data at the NUTS 3 level is publicly available in the ESPON website: http://old.espon.eu/main/Menu_Publications/Menu_TerritorialObservations/trendsinaccessibility.htm

${ }^{8}$ As a calculation example, let's assume that postcode PC belongs to two NUTS 3 regions A and B, where region A has $70 \%$ of the total postcode units of PC and region $\mathrm{B}$ has the remaining $30 \%$. Assuming that NUTS 3 region A has an accessibility index of 100 and region B has an accessibility index of 120, the accessibility index for postcode PC is computed as a weighted average: $106=100 * 0.7+120 * 0.3$.
} 
decision-making authority is located) is related to a lower likelihood of credit constraints (Lee and Brown, 2017; Zhao and Jones-Evans, 2017). The index provides a sub-set of peripheral areas mainly in the South West of England, Scotland and North Wales. ${ }^{9}$ On average, $11.7 \%$ of SMEs in our sample are located in these peripheral areas. A map of these areas is outlined in Figure A1 in the online Appendix.

We also classify SMEs based upon their respective business orientation toward innovation, growth and exporting. SMEs with a growth orientation are those, which aim to grow substantially or moderately over the next year. This group represents $46.2 \%$ of the sample. An SME is innovative if it has developed a new product or service in the past three years. This group represents $15.3 \%$ of the sample. An SME is export-orientated if it sells goods or services abroad. Export oriented SMEs represent $9.6 \%$ of the sample.

A series of covariates are used to account for other differences (which are likely to influence the use of credit card financing) across SMEs. These include firm size, firm profitability, gender and race of main owner, firm age, extent of strategic planning, risk and legal structure. Firm size is measured by total employment according to one of four size categories: 0 employees; 1 to 9 employees; 10 to 49 employees and 50 to 249 employees. The population of SMEs in the UK is characterized by a large proportion of firms with zero employees $(74.1 \%)$ and $1-9$ employees $(22.1 \%)$. It would be expected that larger firms rely more on credit cards as they are more likely to diversify their sources of funding. Profitability is measured using two indicator variables which capture whether a firm has made a profit $(71 \%)$ or a loss $(10 \%)$ in last financial year. SMEs that report net losses during the last financial period are also expected to use credit cards as a source of additional funding to finance their operations. For firms that made a profit during the last financial period, the expected sign is also positive since these firms are in a strong position to consider alternative forms of funding (such as credit cards). We control for cases where 50\% or more of the SME is owned by a female. These SMEs represent $25 \%$ of our sample. If credit cards are a riskier source of financing and female entrepreneurs are more risk-averse than male counterparts (Croson and Gneezy, 2009), we would expect that SMEs controlled by females are less likely to use credit cards. In our sample, the owners of the SMEs in the survey are predominantly white $(91.6 \%)$ and between $31-50$ years old (48\%). We do not have a prior expectation as to

\footnotetext{
${ }^{9}$ The postcode areas included are: Northern Ireland (BT), Carlisle (CA), Dumfries and Galloway (DG), Dorchester (DT), Exeter (EX), the Outer Hebrides (HS), Inverness (IV), Kilmarnock (KA), Orkney (KW), Northern Lancashire (LA), Llandudno (LL), Perth (PH), Plymouth (PL), Taunton (TA), Galashiels (TD), Torquay (TQ), Truro (TR) and Shetland (ZE).
} 
the effect of the ethnic background of an SME owner on credit card usage. However, we would expect that credit card use will be positively related to owner age, given that older owners are more likely to have used different sources of financing over the life of the company. $20 \%$ of the sample are start-ups defined as SMEs founded less than two years prior to the start of the sample period. Although it could be expected that start-ups (2 years old or less) rely on credit cards for financing during early stages of their business, they can also rely on traditional sources such as loans to fund operations during this phase. Therefore, the expected sign of this variable is mixed. $31 \%$ of the SMEs in our sample declared having a business plan in place. SMEs with a formal written business plan are more likely to have a better understanding regarding the availability of various financing sources, and as a consequence are more likely to use credit cards.

We control for creditworthiness by using a credit score for each SME. This credit score is recorded for each SME on a categorical scale ranging from 1 to 4, where: 1 denotes minimal risk; 2 denotes low risk; 3 denotes average risk; and 4 denotes above average risk. Given that the reported credit score of an SME is likely to be endogenous to credit card usage (the credit score is likely to depend partly on the extent to which credit cards are used as a financing tool by SMEs), we use an instrumented credit score in all of the estimated models. Due to the ordinal nature of the credit rating scale from 1 (minimum risk) to 4 (above average risk), we follow Han et al (2009) and Lee and Brown (2017) and estimate an ordered logistic regression (Cameron and Trivedi, 2005) to derive an instrumented credit score for each SME. We control for creditworthiness by using a credit score for each SME. ${ }^{10}$ Around $88 \%$ of SMEs are classified as average or above average risk. The expected sign of this variable is

10 For SME i, we use the following regression specification, where $\mathrm{y}^{*}$ is an unobserved measure of creditworthiness: $y_{i}^{*}=X_{i}^{\prime} \beta+u_{i}$ where the control variables $\left(X_{i}\right)$ include a set of observed SME characteristics including peripheral location, business orientation (innovative, growth-oriented, export-oriented), profitability, business plan availability, firm size, and the gender and age of the owner. For very low $\mathrm{y}^{*}$, credit score represents minimum risk; for $\mathrm{y}^{*}>\alpha_{1}$, credit score moves to low risk, for $\mathrm{y}^{*}>\alpha_{2}$, credit score moves to average risk, and $\mathrm{y}^{*}>\alpha_{3}$, credit score moves to above average risk. For a four option alternative ordered model, we define $y_{i}=j$ if $\alpha_{j-1}<y_{i}^{*} \leq \alpha_{j}, j=1,2,3,4$ where $\alpha_{0}=-\infty$ and $\alpha_{m}=\infty$. Then $\operatorname{Pr}\left(y_{i}=j\right)=$ $\operatorname{Pr}\left(\alpha_{j-1}<y_{i}^{*} \leq \alpha_{j}\right)=F\left(\alpha_{j}-X_{i}^{\prime} \beta\right)-F\left(\alpha_{j-1}-X_{i}^{\prime} \beta\right)$, where $F$ is the cumulative distribution function of $u_{i}$. The regression parameters, $\beta$, and the $m-1$ threshold parameters, $\alpha_{1}, \alpha_{2}, \alpha_{3}$, are obtained maximizing the likelihood with $p_{i j}=\operatorname{Pr}\left(y_{i}=j\right)$ as defined above. The estimated model is then used to obtain predicted probabilities for each of the four outcomes of the dependent variable (predicted probabilities that $y_{i}=$ 1,2,3 or 4) for each SME. The instrumented credit score assigned to each SME corresponds to the category (1, 2,3 or 4) with the highest predicted probability. 
ambiguous. Assuming SMEs can meet monthly minimum payments, utilising credit cards may provide high-risk firms with an opportunity to improve creditworthiness. However, any increase in (credit card) debt and overall leverage may lead to a deterioration in creditworthiness. Finally, we differentiate between sole proprietorships, partnerships, limitedliability partnerships and limited-liability firms to control for differences in legal form. Sole proprietorship (single owner) SMEs represent around 63\% of our sample.

\section{[Insert Table 1 around here]}

\subsection{Methods}

We estimate a probit model to investigate the contribution of our explanatory variables to the probability of an SME using a credit card as a source of funding. SMEs obtain a level of utility $\left(y^{*}\right)$ by using credit cards as a source of funding. This utility captures the benefits that SMEs derive from using credit cards. This includes access to a line of credit without collateral, and the common acceptance of credit cards as a mean of payment. However, instead of providing $y^{*}$, the data used in the present study has information on the actual choice / use of credit cards by SMEs. If $y=1$, a credit card is used by a SME. This implies that the net benefit of using credit cards is positive $\left(y^{*}>0\right)$. Otherwise, if $y=0$, SMEs are better off without credit card financing.

If the utility function is of the form:

$y^{*}=X^{\prime} \beta+\epsilon$

with an unobservable component $(\epsilon)$ that follows a normal distribution $(\Phi(\epsilon))$, and $\left(X^{\prime} \beta\right)$, which includes observable characteristics that modify an SME's utility depending on the unknown parameters $(\beta)$, then the probability that the SME chooses a credit card as a source of financing is:

$\operatorname{Pr}(y=1 \mid X)=\operatorname{Pr}\left(y^{*}>0 \mid X\right)=\operatorname{Pr}\left(\epsilon>-X^{\prime} \beta\right)=\Phi\left(X^{\prime} \beta\right)$

Equation 2 is estimated using maximum-likelihood techniques. The empirical results are reported in terms of average marginal effects of the explanatory variables on the probabilities of the occurrence of $y=1$. The average marginal effects indicate the change in probability when the independent variable switches from the reference category to the 
category in question. The probit model is estimated with the standard errors clustered at the size*region level in order to account for correlation among the outcomes of all SMEs located in the same region (NUTS 1), and that have a similar size (in terms of number of employees). ${ }^{11}$ In addition to the control variables discussed above, our model also includes dummy variables to account for industry and the quarter in which the firm was surveyed. In order to reflect the overall composition of SMEs throughout the UK, our models are estimated with the sampling weights provided in the SME Finance Monitor survey.

\section{Results}

\subsection{The impact of location and SMEs' characteristics on credit card use}

We test $\mathrm{H} 1$ and $\mathrm{H} 2$ by investigating whether peripherally located SMEs and innovative, growth and export-oriented SMEs have a greater use of credit cards compared to counterparts located in core locations, and those counterparts that are non-innovative, nongrowth and non-export oriented. The results reported in Table 2 are derived from the estimation of a full model, which includes all control variables and standard errors clustered at the region*firm size level.

\section{[Insert Table 2 around here]}

For ease of interpretation, all tables report average marginal effects (AMEs), which measure the expected change on the probability of using credit cards when the dependent variable increases by one unit, while keeping all the other independent variables constant at their mean values. Estimated AMEs suggest that SMEs located in peripheral locations have a $2.7 \%-2.8 \%$ higher probability of using credit cards compared to counterparts located in core locations. We also find a positive marginal effect for growth, innovative, and export-oriented SMEs, which have a 3\%, 2.6\%-2.7\% and 5.4\% higher probability respectively of using credit cards relative to their non-growth, non-innovative and non-export-oriented counterparts. This provides strong support to our first (H1) and second (H2) hypotheses. ${ }^{12}$

\footnotetext{
${ }^{11}$ As a robustness check, we also cluster standard errors at sector*region level. Our results remain unchanged, and are available from the authors upon request.

${ }^{12}$ It is possible that SMEs might locate across space based upon on unobservable characteristics, which in turn potentially influence the use of credit cards. Our data does not allow us to further control for additional characteristics which could potentially influence the location choice of SMEs and the use of credit cards. We carry out an additional robustness check to reduce concerns regarding firms deciding to use cards based on unobservable (geographical) characteristics. We re-estimate our baseline Model 4 including a full set of dummy
} 
Moreover, the estimated coefficients on our control variables suggest that large SMEs are more likely to use credit cards than smaller counterparts. Both profitable and net loss SMEs are likely to use credit cards, but the marginal effect is particularly high for SMEs which report net losses in the previous financial period. Start-ups are 5.2\% less likely to use credit cards compared to more established SMEs. Owner age influences the use of credit cards, with older owners more likely to use credit cards compared to younger counterparts (18-29 year olds). Having a business plan increases the probability of using a credit card by $2.3 \%$. Finally, SMEs with above average credit risk are less likely to use credit cards compared to more creditworthy counterparts.

\subsection{The interaction between location and SMEs' characteristics and credit card use}

Table 2 also reports estimated coefficients for the interaction terms between business orientation (growth, innovation and export-orientation) and location. Computing the magnitude of the interaction effect in nonlinear models is non-trivial as it does not equal the marginal effect of the interaction term (Ai and Norton, 2003). Thus, to provide a meaningful interpretation of the interaction terms, we compute the difference between the predicted probabilities for the interaction terms reported in Table 2, while keeping constant either business orientation or location (Williams, 2012). The results of this difference along with the statistical significance are reported in Figures A2 and A3 in the online appendix. These results suggest that peripherally located growth orientated SMEs have a higher probability of using credit cards than their non-peripherally (core) located counterparts, but this effect is not present in innovative and export-oriented SMEs. Moreover, within peripheral areas, growth, innovative, and export-oriented SMEs have a higher probability of using credit cards than non-growth, non-innovative and non-export orientated counterparts. As such our results provide strong empirical support for the notion that the interaction between location and business orientation is a significant driver of SME credit card use.

To provide corroborating evidence in support of our findings, we implement a robustness check and use 'lagging' regions as an alternative measure of peripheral location (Lee and Brown, 2017). Lagging regions are defined as geographic areas where GDP is below the EU average. Lagging UK regions include: (i) less developed regions with less than $75 \%$ of the EU average GDP; and transition regions with GDP between $75 \%$ and $90 \%$ of the

variables for each of the postcodes where the firm is located. The results remain largely unchanged and are available from the authors upon request. We are indebted to an anonymous referee for raising this issue. 
EU average GDP. The estimations using lagging regions rather than peripheral location provide similar results to those reported in Figures A2 and A3 (of the online appendix). ${ }^{13}$

\subsection{Credit Cards as a Bootstrapping tool for SMEs}

Table 3 provides the results of testing our hypothesis $\mathrm{H} 3$, which investigate the use of credit cards as a bootstrapping tool. We use the full model described above, but now the key dependent (indicator) variable captures whether a SME is very likely or fairly likely to apply for more external finance in the next three months. The reported results provide strong support for H3. SMEs currently using credit cards have a $4.5 \%$ higher probability of applying for more external finance compared to counterparts not using credit cards.

\section{[Insert Table 3 around here]}

To facilitate the interpretation of the estimated coefficients of the interaction terms between SME location and business orientation reported in Table 3, we follow the same methodology described previously. Our results reported in Figures A4 to A6 of the online appendix suggest that: keeping location constant, SME credit card users have a higher probability of applying for new finance compared to counterparts not using credit cards (Figure A4); keeping business orientation constant, SMEs using cards have a greater likelihood of applying for further external finance compared to SMEs that are not credit card users (Figure A5); and among those SMEs currently using cards, both innovative and growthoriented SMEs have a stronger propensity to apply for further external finance compared to non-innovative and non-growth counterparts (Figure A6).

\section{Conclusion}

Informational opaqueness can make it difficult for SMEs to access finance from banks and other investors, constraining day-to-day activities and potentially impeding longer term strategic investments. As a consequence, SMEs may seek alternative sources of finance (such as credit cards) that are often easier to secure in the absence of collateral, but which may represent a more expensive form of funding. ${ }^{14}$ While penalised with high levels of interest

\footnotetext{
${ }^{13}$ These robustness results are not reported, but are available from the authors upon request.

${ }^{14}$ In order to justify this reasoning, we carry out an additional empirical exercise to analyse the impact of being turned down for a loan/overdraft facility on the likelihood of SMEs applying for a credit card in the next three months. The analysis focuses on a small sample of SMEs which were not using credit cards at the time of the survey. Although results for loan rejection are not statistically significant, we find strong evidence that the failure to get access to finance via overdraft facilities increases in $11.6 \%$ the probability of applying for a credit
} 
some less risk-adverse SMEs may therefore "stick it on plastic" as a worthwhile expedient solution to gaining quick access to finance in the presence of credit constraints.

In this paper, we investigate the use of credit cards by UK SMEs and how this varies by business orientation and location. We find that SMEs located in peripheral geographic areas have a greater use of credit cards than counterparts located in 'core' locations. In terms of business orientation, we find that innovative, growth and export-oriented SMEs have a stronger predilection for credit card financing. This is unsurprising given that these firms are likely to be more informationally opaque and as a consequence more likely to face problems accessing traditional sources of finance. Innovative, growth and export oriented SMEs located in peripheral geographic locations relying on credit cards as a source of funding are likely to apply for different funding sources in the future. This suggests that some SMEs use credit cards as a 'bootstrapping' technique which eventually leads toward the use of more traditional (longer-term and lower cost) forms of finance.

The findings presented in this study raise important theoretical and empirical questions, both in terms of the demand and supply of SME finance. In terms of demand, credit cards may be an important form of improvisational finance used by innovative entrepreneurial firms. Based on the evidence presented in the current study, it appears that innovative SMEs use credit cards to overcome temporal resource constraints with a view towards leveraging further additional sources of external finance. In terms of credit supply, the findings of the present study also have important implications for the wider literature on the geographical variability of SME access to finance across the UK. It appears to be the case that a lack of supply of finance in certain areas may have an impact on the extent to which alternative sources of finance are sought. Credit card usage may therefore be part of the wider systemic process in which so-called thin markets encompass a wider array of funding instruments than purely conventional debt and equity finance.

While the policy implications arising from these findings remain somewhat ambiguous, it seems appropriate policy makers highlight the potential problems SMEs could potentially encounter from becoming too reliant on this costly form of finance. In spite of the advantages unsecured credit card finance offers to SMEs, easy access to funding can expose SMEs to additional costs and risks. Using credit cards to cover long-term financial needs could result in substantial late payment charges fees whilst incurring interest rate payments

card in the next 3 months. In order to conserve space, these results are not reported. However, these results are available from the authors upon request. 
much higher than those applied to loans and bank overdrafts. Credit cards are complex financial instruments which include a range of different interest rates triggered under certain events or transactions (e.g. different types of balances). This complexity and lack of transparency with their terms and conditions can lead SMEs to pay additional fees and higher interest rates. Furthermore, a late payment can negatively impact a firm's credit score, making it hard to apply for a loan in the future.

Further empirical work exploring the disadvantages of using credit cards for SMEs is clearly needed to understand the nature of these factors in order to design more effective access to finance policies for SMEs. What seems abundantly clear from the results of this study is the critical importance of further unravelling the capital structures across different types of SMEs.

\section{References}

Ai, C., \& Norton, E. C. (2003). Interaction terms in logit and probit models. Economics Letters, 80(1), 123-129.

BDRC. (2016) SME Finance Monitor. Available online at: http://bdrc-continental.com/ products/sme-finance-monitor/.

Berger, A. N., \& Udell, G. F. (1998) The economics of small business finance: The roles of private equity and debt markets in the financial growth cycle. Journal of Banking \& Finance, 22(6), 613-673.

BIS (2016) SME lending and competition: an international comparison of markets. BIS Research Papers Number 270. London: UK

Blanchflower, D.G., \& Evans, D.S. (2004) The Role of Credit Cards in Providing Financing for Small Businesses. Payment Card Economics Review 2 (Winter), 77-95.

Brown, R., Mawson, S., Rowe, A. \& Mason, C. (2017) Working the Crowd: Improvisational Entrepreneurship and Equity Crowdfunding in Nascent Entrepreneurial Ventures, International Small Business Journal,36(2) 169-193.

Cameron, A. C., \& Trivedi, K. P. (2005). Microeconometrics: Methods and applications. New York, NY: Cambridge University Press

Cosh, A., Cumming, D., \& Hughes, A. (2009). Outside enterpreneurial capital. The Economic Journal, 119(540), 1494-1533.

Croson, R., \& Gneezy, U. (2009). Gender Differences in Preferences. Journal of Economic Literature, 47(2), 448-74. 
Deutsche Bank (2009) Brave New Firms: High Tech Entrepreneurship in the United States, Deutsche Bank Research. Available at: http://www.dbresearch.com/PROD/DBR_INTERNET_ENPROD/PROD0000000000251554.PDF

Ebben, J., \& Johnson, A. (2006). Bootstrapping in small firms: An empirical analysis of change over time. Journal of Business Venturing, 21(6), 851-865.

ESPON. (2009). Territorial Dynamics in Europe: Trends in Accessibility. Luxembourg: ESPON.

Financial Times (2018) Success tastes sweet for Halo Top as ice cream sales soar, January $17^{\text {th }} 2018$.

Han, L., Fraser, S., \& Storey, D. J. (2009) Are good or bad borrowers discouraged from applying for loans? Evidence from US small business credit markets. Journal of Banking \& Finance, 33(2), 415-424.

Harrison, R. T., Mason, C. M., \& Girling, P. (2004) Financial bootstrapping and venture development in the software industry. Entrepreneurship \& Regional Development, 16(4), 307-333.

Hesse, J. (2012) SME Owners Owe $£ 30,000$ each on average, Real Business, http://realbusiness.co.uk/accounts-and-tax/2012/04/10/sme-owners-owe-30000-each-onaverage/

Lee, N., Sameen, H., \& Cowling, M. (2015). Access to finance for innovative SMEs since the financial crisis. Research policy, 44(2), 370-380.

Lee, N., \& Brown, R. (2017) Innovation, SMEs and the liability of distance: the demand and supply of bank funding in UK peripheral regions. Journal of Economic Geography, 17(1), 233-260.

Mach, T.L. \& Wolken, J.D. (2006) Financial Services Used by Small Businesses: Evidence from the 2003 Survey of Small Business Finances. Federal Reserve Bulletin, October: 16795.

Mason, C., \& Brown, R. (2013). Creating good public policy to support high-growth firms. Small Business Economics, 40(2), 211-225.

Myers, S. C., \& Majluf, N. S. 1984. Corporate financing and investment decisions when firms have information that investors do not have. Journal of financial economics, 13(2), 187221.

Nightingale, P., Murray, G., Cowling, M., Baden-Fuller, C., Mason, C., Siepel, J. \& Dannreuther, C. (2009) From Funding Gaps to Thin Markets: UK Government Support for Early-stage Venture Capital. London: NESTA.

Owen, R., Bothelo, T., \& Anwar, O. (2016) Exploring the success and barriers to access to SME Finance and its potential role in achieving growth, ERC Research Paper Number 53.

Robb, A. M., \& Robinson, D. T. (2014). The capital structure decisions of new firms. The Review of Financial Studies, 27(1), 153-179. 
Scott, R. (2009) Plastic Capital: Credit Card Debt and New Small Business Survival.\| Kaufman Foundation.

Udell, G. F. (2015) SME Access to Intermediated Credit: What Do We Know, and What Don't We Know? Reserve Bank of Australia, Conference Volume.

UK Cards Association (2014) Annual Report 2014, The UK Cards Association, London.

Wille, D. Hoffer, A. \& Miller, S.M. (2017) Small-business financing after the financial crisis: lessons from the literature, Journal of Entrepreneurship and Public Policy, 6 (3), 315-339.

Williams, R. (2012). Using the margins command to estimate and interpret adjusted predictions and marginal effects. Stata Journal, 12(2), 308.

Zhao, T., \& Jones-Evans, D. (2017) SMEs, banks and the spatial differentiation of access to finance. Journal of Economic Geography, 17 (4), 791-824. 
Table 1. Description of variables and descriptive statistics

\begin{tabular}{|c|c|c|c|c|c|c|}
\hline Variable & Details & Observations & $\begin{array}{c}\text { Mean } \\
\text { (survey weighted) } \\
\end{array}$ & $\begin{array}{l}\text { Standard } \\
\text { Deviation } \\
\end{array}$ & Minimum & Maximum \\
\hline Credit Card Use & SME is currently using a credit card & 50,137 & 0.157768 & .3645267 & 0 & 1 \\
\hline Apply for more finance & $\begin{array}{l}\text { SME is "very likely" or "fairly likely" to apply for } \\
\text { more external finance in the next } 3 \text { months }\end{array}$ & 50,136 & 0.075781 & .2646503 & 0 & 1 \\
\hline Peripheral SME & SME located in peripheral postcode area & 50,136 & 0.116579 & .3209211 & 0 & 1 \\
\hline Aims to grow & SME aims to grow substantially or moderately over & 50,137 & 0.461828 & .4985457 & 0 & 1 \\
\hline Innovative & $\begin{array}{l}\text { SME has developed a new product or service in the } \\
\text { past } 3 \text { years }\end{array}$ & 50,137 & 0.153385 & .3603617 & 0 & 1 \\
\hline SME exports & SME sells goods or services abroad & 50,137 & 0.096306 & .2950129 & 0 & 1 \\
\hline \multicolumn{7}{|l|}{ Employment size: } \\
\hline 0 & & 50,137 & 0.740892 & .4381495 & 0 & 1 \\
\hline $1-9$ & & 50,137 & 0.221606 & .4153314 & 0 & 1 \\
\hline $10-49$ & & 50,137 & 0.031702 & .1752068 & 0 & 1 \\
\hline $50-249$ & & 50,137 & 0.005801 & .0759406 & 0 & 1 \\
\hline Loss & SME made loss in last financial year & 50,137 & 0.107194 & .3093631 & 0 & 1 \\
\hline Profit & SME made profit in last financial year & 50,137 & 0.718808 & .4495857 & 0 & 1 \\
\hline Women owned & $50 \%$ or more of the SME owned by women & 50,137 & 0.252802 & .4346226 & 0 & 1 \\
\hline Start-up & SME is 2 years old or younger & 50,137 & 0.200000 & .400004 & 0 & 1 \\
\hline Owner's ethnic background: White & $\begin{array}{l}\text { Owner's ethnic background is white (British, Irish or } \\
\text { any other white background) }\end{array}$ & 48,679 & 0. .935277 & .2460387 & 0 & 1 \\
\hline \multicolumn{7}{|c|}{ сал } \\
\hline $18-30$ & & 48,048 & 0.059086 & .2357875 & 0 & 1 \\
\hline $31-50$ & & 48,048 & 0.480221 & .4996138 & 0 & 1 \\
\hline $51+$ & & 48,048 & 0.460694 & .4984578 & 0 & 1 \\
\hline Business Plan & SME has business plan & 50,137 & 0.316528 & .465126 & 0 & 1 \\
\hline \multicolumn{7}{|l|}{ Instrumented credit score: } \\
\hline Minimal & & 45,649 & 0.002357 & .0484891 & 0 & 1 \\
\hline Low & & 45,649 & 0.093903 & .2916972 & 0 & 1 \\
\hline Average & & 45,649 & 0.281165 & .4495727 & 0 & 1 \\
\hline Above average & & 45,649 & 0.622575 & .4847479 & 0 & 1 \\
\hline \multicolumn{7}{|l|}{ Legal Status of SME: } \\
\hline$S P$ & Sole Proprietorship (single owner) & 50,137 & 0.635706 & .4812364 & 0 & 1 \\
\hline Partnership & Partnership & 50,137 & 0.050026 & .2180009 & 0 & 1 \\
\hline$L L P$ & Limited Liability Partnership & 50,137 & 0.023192 & .1505147 & 0 & 1 \\
\hline$L L C$ & Limited Liability Company (private limited company, & 50,137 & 0.291076 & .4542629 & 0 & 1 \\
\hline
\end{tabular}


Table 2. The interaction between location and SME characteristics and their effect on credit card use

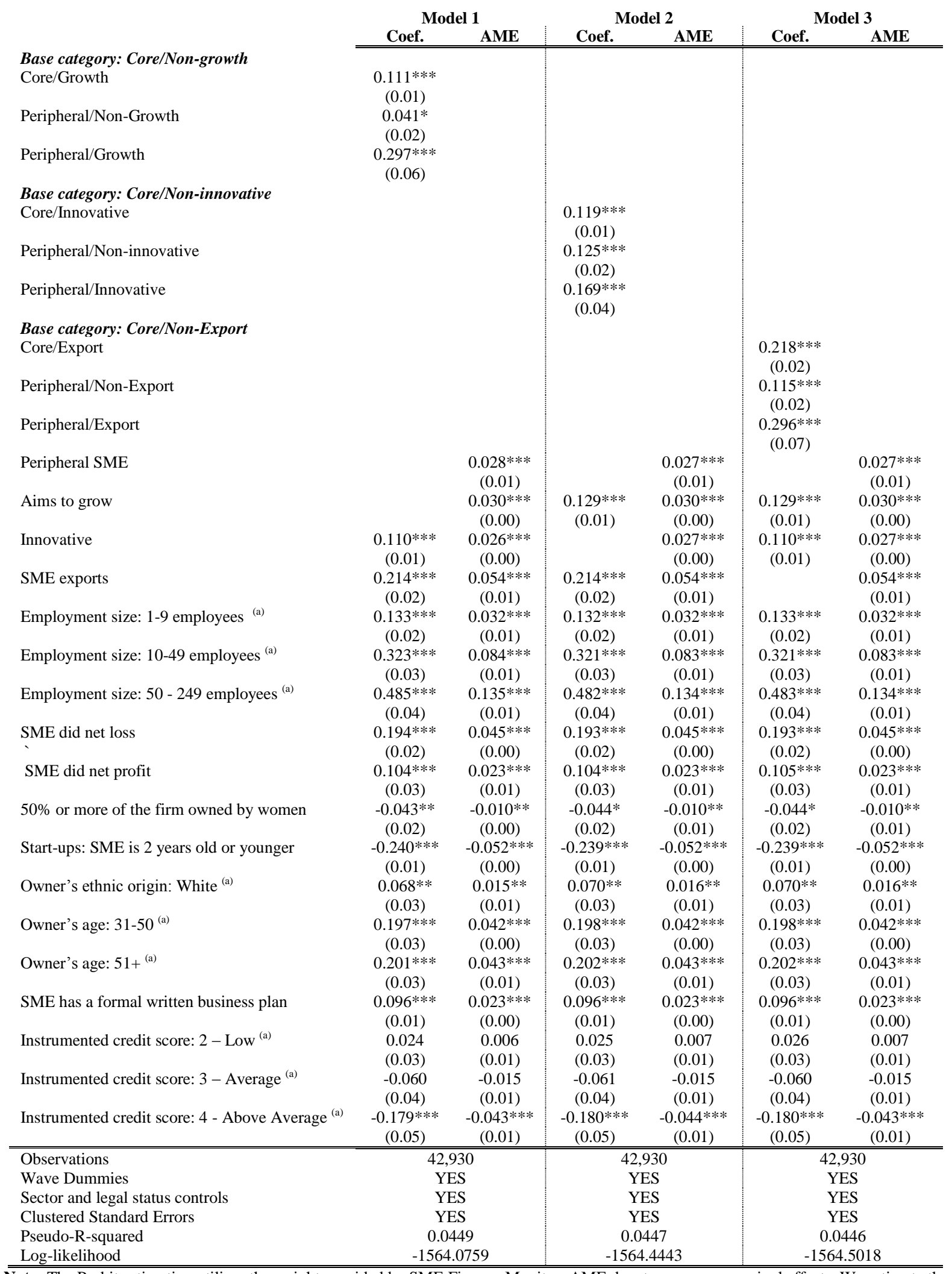

Note: The Probit estimation utilizes the weight provided by SME Finance Monitor. AME denotes average marginal effects. We estimate the instrumented credit scores by conducting ordered logistic models on the SME's characteristics. One instrumented Credit Score follows the categorical nature of the underlying score from 1 to 4 , where 1 is 'minimal', 2 is 'low risk', 3 is 'average risk', 4 is 'above average risk'. The score is recorded to a specific category where the sample firm has the highest probability of falling into this category. ${ }^{\text {(a) }}$ The excluded variables for the demographic categories above are as follows: Zero employees (employment size), other ethnic origin (owner's ethnic origin), 18-30 years old (owner's age), 1- minimal (instrumented credit score). Standard errors clustered at the size (i.e. employment size)* region level in parentheses. $* * *, * *$ and $*$ refer to $1 \%, 5 \%$ and $10 \%$ significance levels respectively. 
Table 3. Credit Cards as a Bootstrapping tool

Base category: Non-Credit Card user/Core

Non-Credit card user/ Peripheral

Credit Card user/Core

Credit Card user/Peripheral

Base category: Non-Credit Card user/Non-growth

Non-Credit card user/ Growth

Credit Card user/Non-growth

Credit Card user/ Growth

Base category: Non-Credit Card user/Non-innovative Non-Credit card user/ Innovative

Credit Card user/ Non-innovative

Credit Card user/Innovative

Base category: Non-Credit Card user/Non-exporter

Non-Credit card user/ Exporter

Credit Card user/ Non-exporter

Credit Card user/ Exporter

\section{Credit Card user}

Peripheral SME

Aims to grow

Innovative

SME exports

Employment size: 1-9 employees ${ }^{(a)}$

Employment size: 10-49 employees ${ }^{\text {(a) }}$

Employment size: 50 - 249 employees ${ }^{\text {(a) }}$

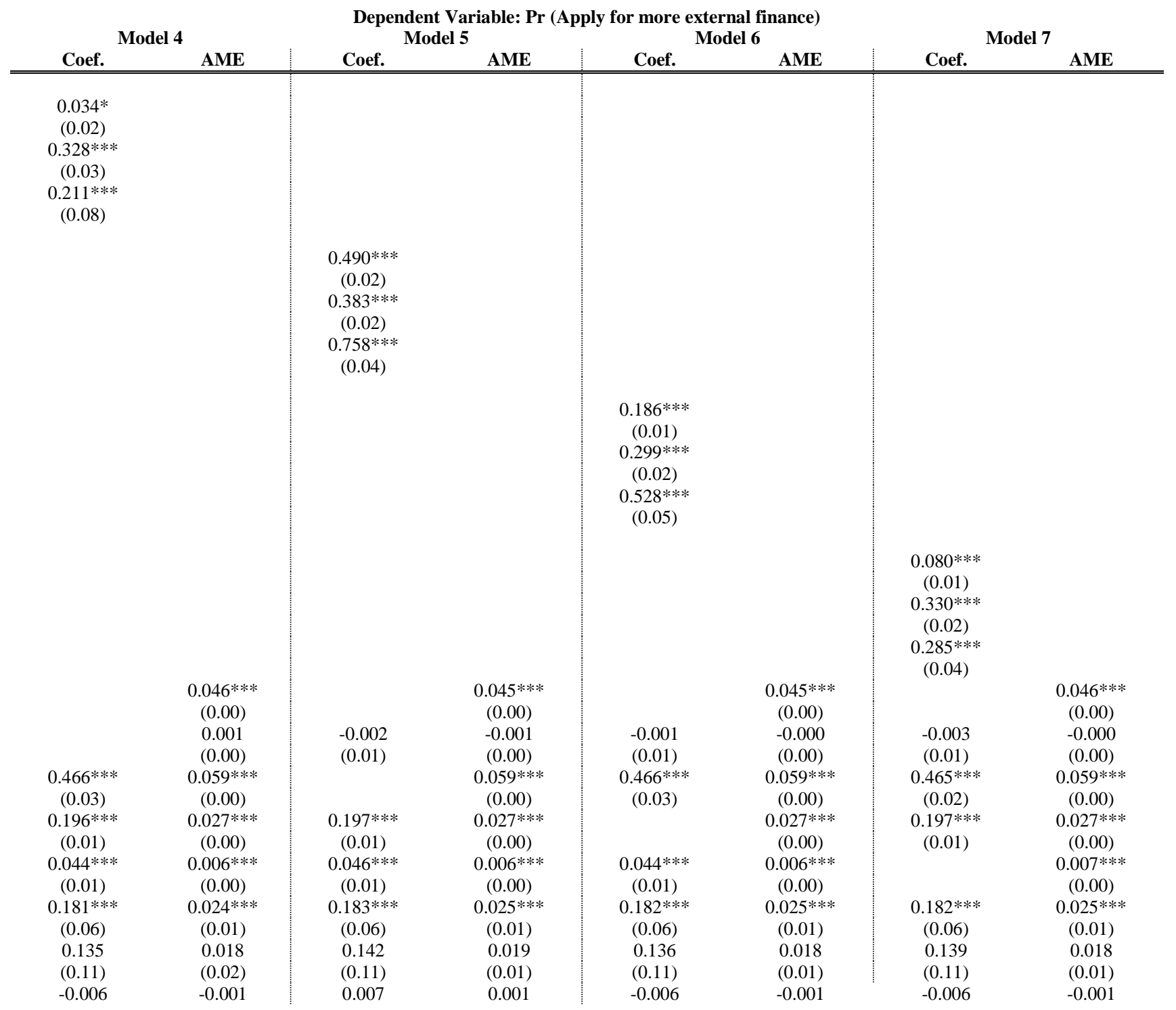




\section{SME did net loss}

SME did net profit

$50 \%$ or more of the firm owned by women

Start-ups: SME is 2 years old or younger

Owner's ethnic origin: White ${ }^{(\mathrm{a})}$

Owner's age: $31-50^{\text {(a) }}$

Owner's age: $51+^{(\mathrm{a})}$

SME has a formal written business plan

Instrumented credit score: $2-$ Low $^{(a)}$

Instrumented credit score: 3 - Average ${ }^{\text {(a) }}$

\section{Observations}

ummies

Sector and legal status controls

Pseudo-R-square
Instrumented credit score: 4 - Above Average ${ }^{(a)}$

Clustered Standard Error

\begin{tabular}{|c|c|c|c|c|c|c|c|}
\hline$(0.13)$ & $(0.02)$ & $(0.12)$ & $(0.01)$ & (0.13) & $(0.02)$ & $(0.13)$ & $(0.01)$ \\
\hline $\begin{array}{c}0.371 * * * \\
(0.02)\end{array}$ & $\begin{array}{c}0.062 * * * \\
(0.00)\end{array}$ & $\begin{array}{c}0.370^{* * *} * \\
(0.02)\end{array}$ & $\begin{array}{c}0.062 * * * \\
(0.00)\end{array}$ & $\begin{array}{c}0.370^{* * * *} \\
(0.02)\end{array}$ & $\begin{array}{c}0.062 * * * \\
(0.00)\end{array}$ & $\begin{array}{c}0.370^{* * * *} \\
(0.02)\end{array}$ & $\begin{array}{c}0.062 * * * \\
(0.00)\end{array}$ \\
\hline$-0.108^{* * * *}$ & $-0.013^{* * *}$ & $-0.107^{* * * *}$ & $-0.013^{* * * *}$ & $-0.108^{* * *}$ & $-0.013 * * *$ & $-0.109 * * *$ & $-0.014 * * *$ \\
\hline$(0.03)$ & $(0.00)$ & $(0.03)$ & $(0.00)$ & $(0.03)$ & $(0.00)$ & $(0.03)$ & $(0.00)$ \\
\hline $\begin{array}{c}-0.064 * * \\
(0.03)\end{array}$ & $\begin{array}{c}-0.008^{* *} * \\
(0.00)\end{array}$ & $\begin{array}{c}-0.064^{* * *} \\
(0.03)\end{array}$ & $\begin{array}{c}-0.008 * * \\
(0.00)\end{array}$ & $\begin{array}{c}-0.064 * * \\
(0.03)\end{array}$ & $\begin{array}{c}-0.008^{* *} \\
(0.00)\end{array}$ & $\begin{array}{c}-0.064 * * \\
(0.03)\end{array}$ & $\begin{array}{c}-0.008^{* *} \\
(0.00)\end{array}$ \\
\hline $0.142 * * *$ & 0.019 *** & $0.141 * * *$ & 0.019 *** & 0.142 *** & $0.019 * * *$ & $0.141 * * *$ & $0.019 * * *$ \\
\hline$(0.01)$ & $(0.00)$ & $(0.01)$ & $(0.00)$ & $(0.01)$ & $(0.00)$ & $(0.01)$ & $(0.00)$ \\
\hline $\begin{array}{c}-0.456 * * * \\
(0.04)\end{array}$ & $\begin{array}{c}-0.075 * * * \\
(0.01)\end{array}$ & $\begin{array}{c}-0.456 * * * \\
(0.04)\end{array}$ & $\begin{array}{c}-0.075 * * * \\
(0.01)\end{array}$ & $\begin{array}{c}-0.456 * * * \\
(0.04)\end{array}$ & $\begin{array}{c}-0.075^{* * * *} \\
(0.01)\end{array}$ & $\begin{array}{c}-0.455^{* * *} * \\
(0.04)\end{array}$ & $\begin{array}{c}-0.074 * * * \\
(0.01)\end{array}$ \\
\hline$-0.240 * * *$ & $-0.037 * * *$ & $-0.238 * * *$ & $-0.036^{* * * *}$ & $\begin{array}{c}(0.04) \\
-0.240^{* * * *}\end{array}$ & $-0.037 * * *$ & $-0.239 * * *$ & $-0.036^{* * * *}$ \\
\hline$(0.08)$ & $(0.01)$ & $(0.08)$ & $(0.01)$ & $(0.08)$ & $(0.01)$ & $(0.08)$ & $(0.01)$ \\
\hline-0.318 *** & $-0.046 * * *$ & $-0.316^{* * * *}$ & $-0.046 * * *$ & $-0.317 * * *$ & $-0.046^{* * * *}$ & $-0.317 * * *$ & $-0.046 * * *$ \\
\hline$(0.09)$ & $(0.01)$ & $(0.09)$ & $(0.01)$ & $(0.09)$ & $(0.01)$ & $(0.09)$ & $(0.01)$ \\
\hline $0.125^{* * *}$ & $0.016^{* * * *}$ & $0.124 * * *$ & $0.016^{* * * *}$ & $0.125^{* * *}$ & $0.016^{* * *}$ & $0.124 * * *$ & $0.016^{* * * *}$ \\
\hline$(0.04)$ & $(0.00)$ & $(0.04)$ & $(0.00)$ & $(0.04)$ & $(0.00)$ & $(0.04)$ & $(0.00)$ \\
\hline $0.101 *$ & $0.011 * *$ & $0.110 * *$ & $0.012 * *$ & $0.103 *$ & $0.011^{* *}$ & 0.087 & $0.009^{*}$ \\
\hline$(0.06)$ & $(0.01)$ & $(0.05)$ & $(0.01)$ & $(0.06)$ & $(0.01)$ & $(0.06)$ & $(0.01)$ \\
\hline $0.205^{* * * *}$ & $0.024 * * *$ & $0.219 * * *$ & $0.025^{* * * *}$ & $0.208^{* * * *}$ & $0.024 * * *$ & $0.191 * * *$ & $0.022 * * *$ \\
\hline$(0.07)$ & $(0.01)$ & $(0.07)$ & $(0.01)$ & $(0.07)$ & $(0.01)$ & $(0.07)$ & $(0.01)$ \\
\hline $0.180^{*}$ & $0.021 *$ & $0.194 *$ & $0.022 *$ & $0.184 *$ & $0.021 *$ & 0.167 & 0.019 \\
\hline$(0.11)$ & $(0.01)$ & $(0.11)$ & $(0.01)$ & $(0.11)$ & $(0.01)$ & $(0.11)$ & $(0.01)$ \\
\hline \multicolumn{2}{|c|}{ "42,930 } & \multicolumn{2}{|c|}{42,930} & \multicolumn{2}{|c|}{42,930} & \multicolumn{2}{|c|}{$\begin{array}{l}42,930 \\
\end{array}$} \\
\hline \multicolumn{2}{|c|}{$\begin{array}{l}\text { YES } \\
\text { YES }\end{array}$} & \multicolumn{2}{|c|}{ YES } & \multicolumn{2}{|c|}{$\mathrm{YI}$} & \multicolumn{2}{|c|}{ YES } \\
\hline \multicolumn{2}{|c|}{ YES } & \multicolumn{2}{|c|}{ YES } & \multicolumn{2}{|c|}{ YES } & \multicolumn{2}{|c|}{ YES } \\
\hline \multirow{2}{*}{\multicolumn{2}{|c|}{$\begin{array}{c}\text { YES } \\
0.1067\end{array}$}} & \multirow{2}{*}{\multicolumn{2}{|c|}{$\begin{array}{l}\mathrm{TES} \\
0.1068\end{array}$}} & \multirow{2}{*}{\multicolumn{2}{|c|}{$\begin{array}{l}\text { YES } \\
01066\end{array}$}} & \multirow{2}{*}{\multicolumn{2}{|c|}{$\begin{array}{l}\text { YES } \\
01067\end{array}$}} \\
\hline & & & & & & & \\
\hline \multicolumn{2}{|c|}{-889.32535} & \multicolumn{2}{|c|}{-889.26887} & \multicolumn{2}{|c|}{-889.48683} & \multicolumn{2}{|c|}{-889.34494} \\
\hline
\end{tabular}

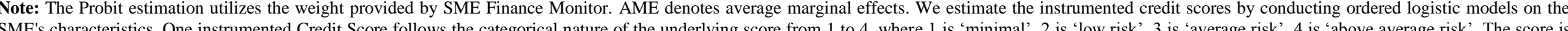
recorded to a specific category where the sample firm has the highest probability of falling into this category. (a) The excluded variables for the demographic categories above are as follows: Zero employees (employment size), other ethnic origin (owner's ethnic origin), 18-30 years old (owner's age), 1- minimal (instrumented credit score). Standard errors clustered at the size (i.e. employment size) * region level in parentheses. $* * *, * *$ and $*$ refer to $1 \%, 5 \%$ and $10 \%$ significance levels respectively. 


\section{On-Line Appendix}

\section{Sticking it on Plastic: Credit Card Finance and Small and Medium Sized Enterprises in the UK}

Figure A1. Peripheral postcode areas

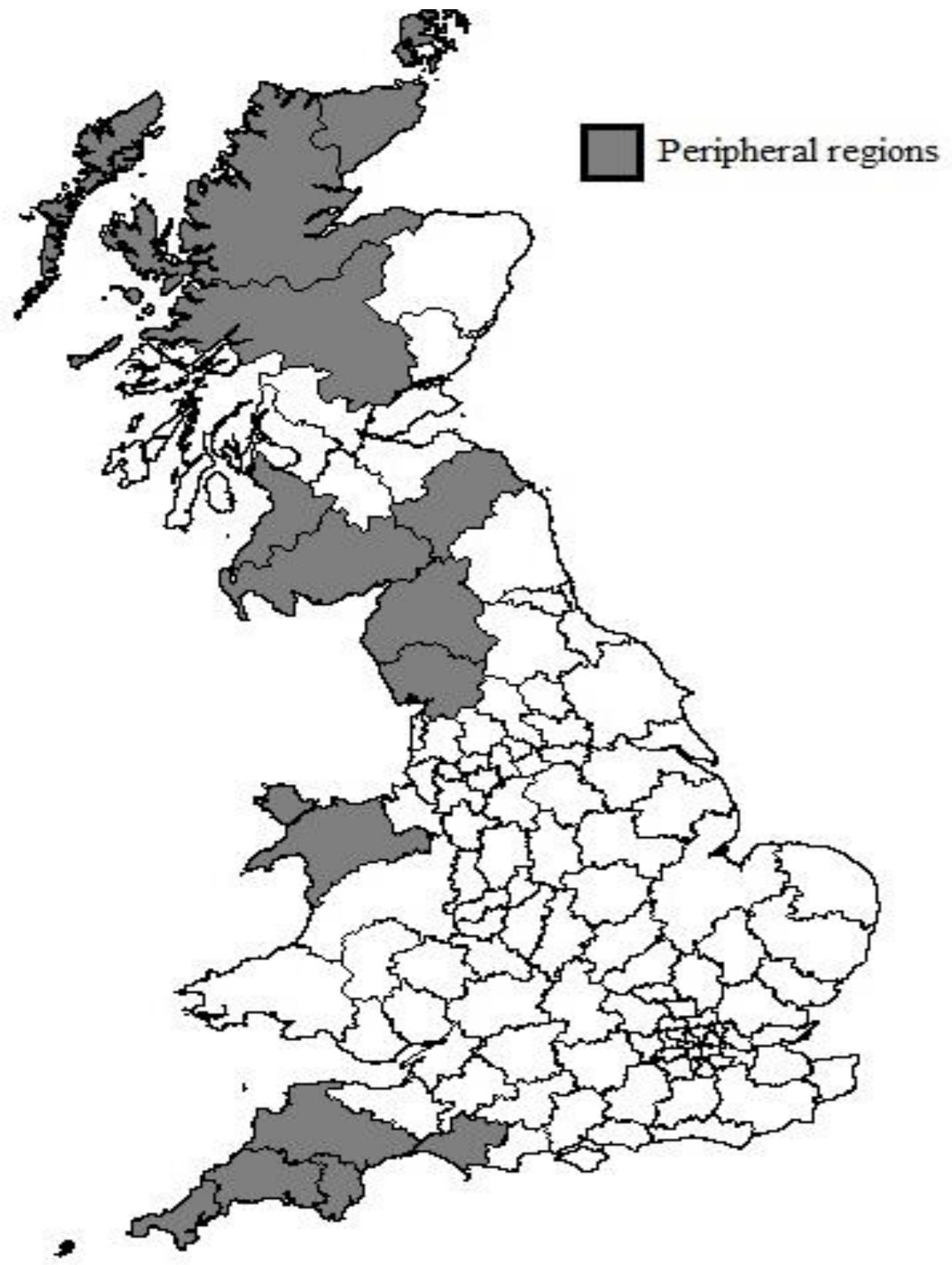

Note: This Figure shows peripheral postcode areas according to travel time using road, rail and air following the methodology proposed by Lee and Brown (2017). 
Figure A2. Estimates of the differences in probability of using cards between Peripheral and Nonperipheral (core) SMEs by orientation type

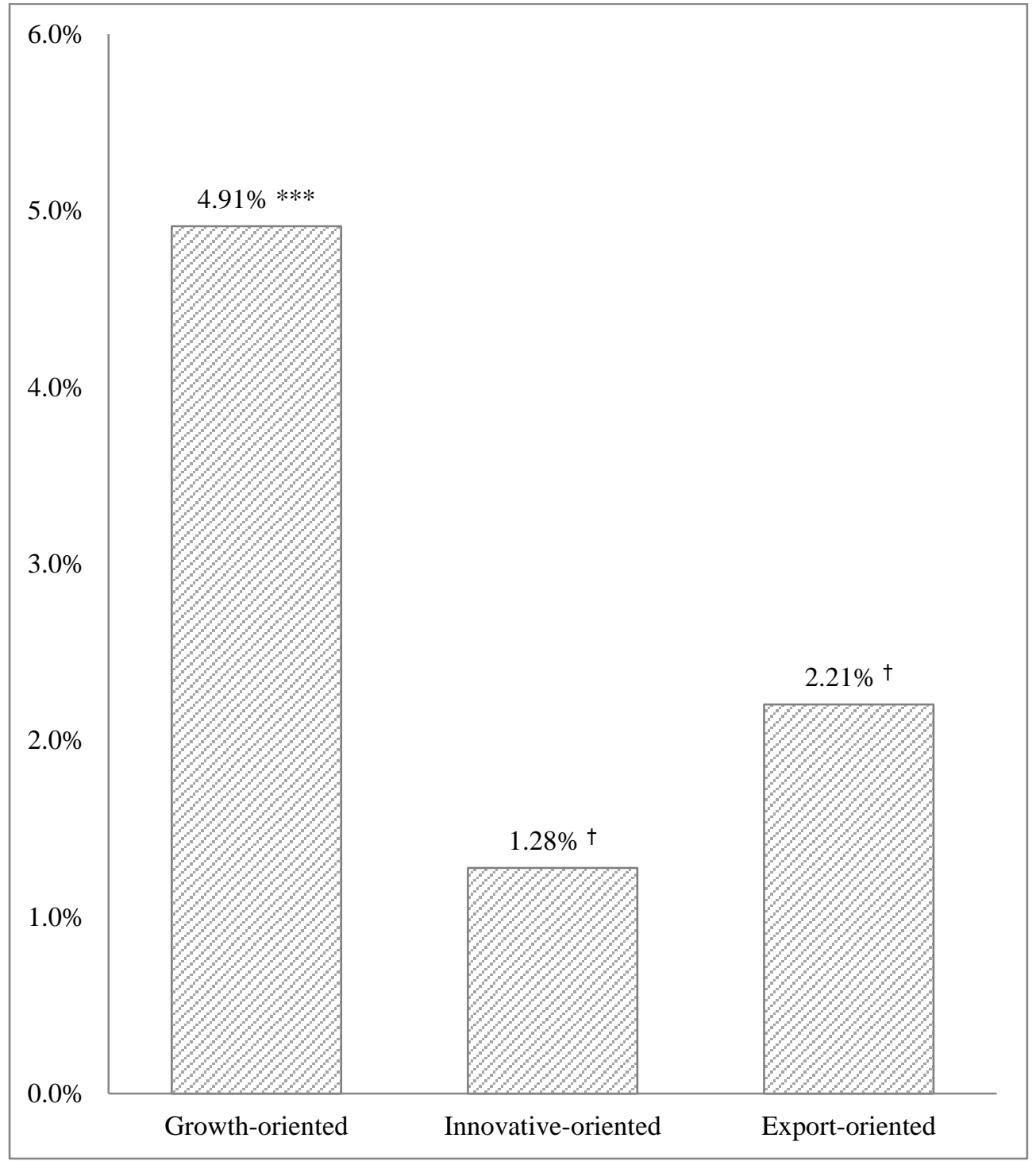

Notes: This Figure shows estimates of the differences in predicted probabilities of using cards between Peripheral and Non-peripheral (core) SMEs when orientation type is held constant. ***, ** and * refer to $1 \%$, $5 \%$ and $10 \%$ significance levels respectively. $†$ refers to not statistically significant results. 
Figure A3. Estimates of the differences in probability of using cards among SMEs located in peripheral areas by orientation type

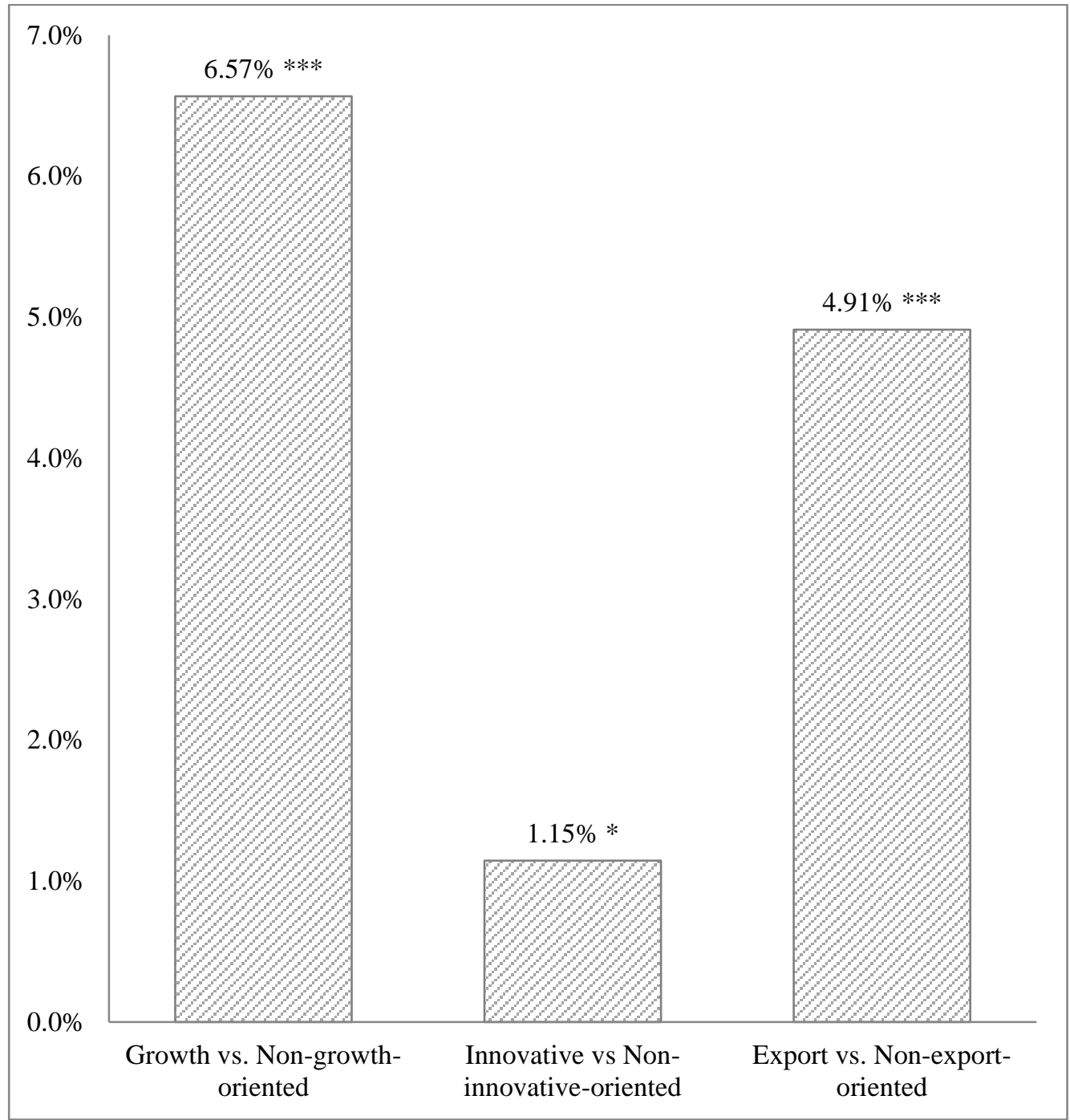

Notes. This Figure shows estimates of the differences in predicted probabilities of using cards between SMEs with different business orientations in peripheral locations. $* * *, * *$ and $*$ refer to $1 \%, 5 \%$ and $10 \%$ significance levels respectively. 
Figure A4. Estimates of the differences in probability of applying for new finance between SMEs using credit cards and SMEs not using credit cards by location

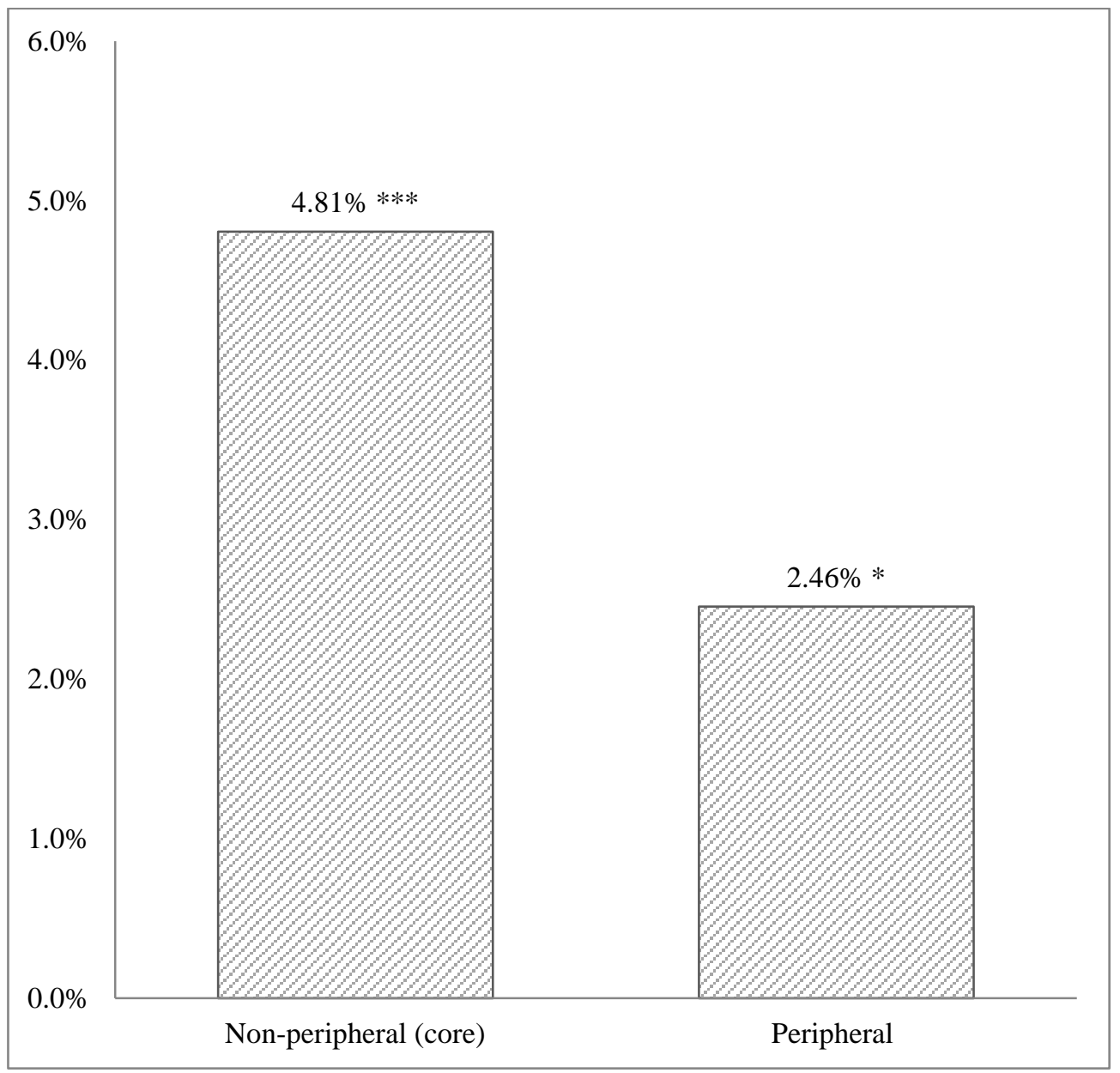

Notes: This Figure shows estimates of the differences in predicted probabilities of applying for new finance between SMEs using credit cards and SMEs not using credit cards when location type is held constant. ***, ** and $*$ refer to $1 \%, 5 \%$ and $10 \%$ significance levels respectively. 
Figure A5. Estimates of the differences in probability of applying for new finance between SMEs using credit cards and SMEs not using credit cards by business orientation

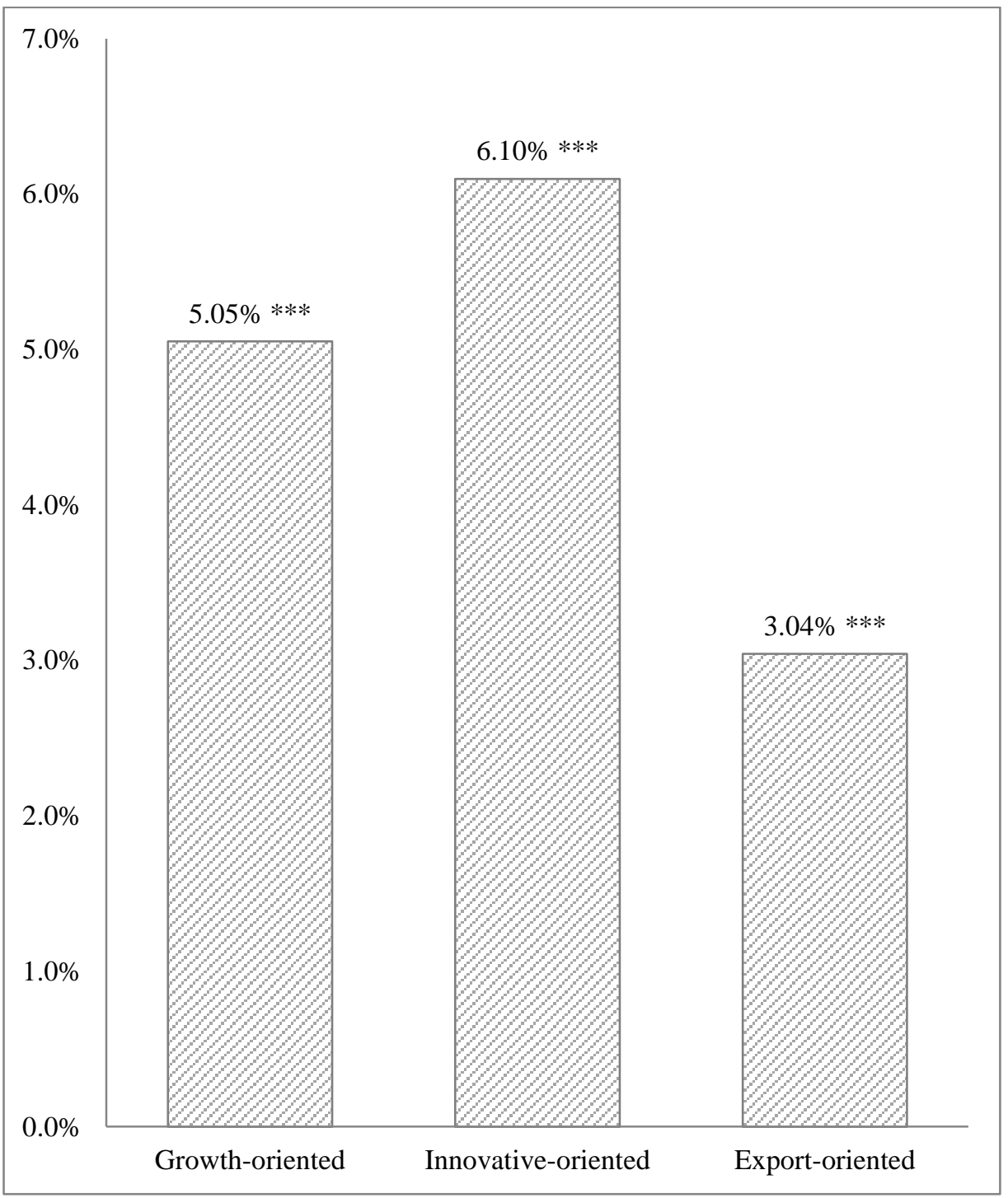

Notes: This Figure shows estimates of the differences in predicted probabilities of applying for new finance between SMEs using credit cards and SMEs not using credit cards when orientation type is held constant. ***, $* *$ and $*$ refer to $1 \%, 5 \%$ and $10 \%$ significance levels respectively. 
Figure A6. Estimates of the differences in probability of applying for new finance among SMEs using credit cards by business orientation

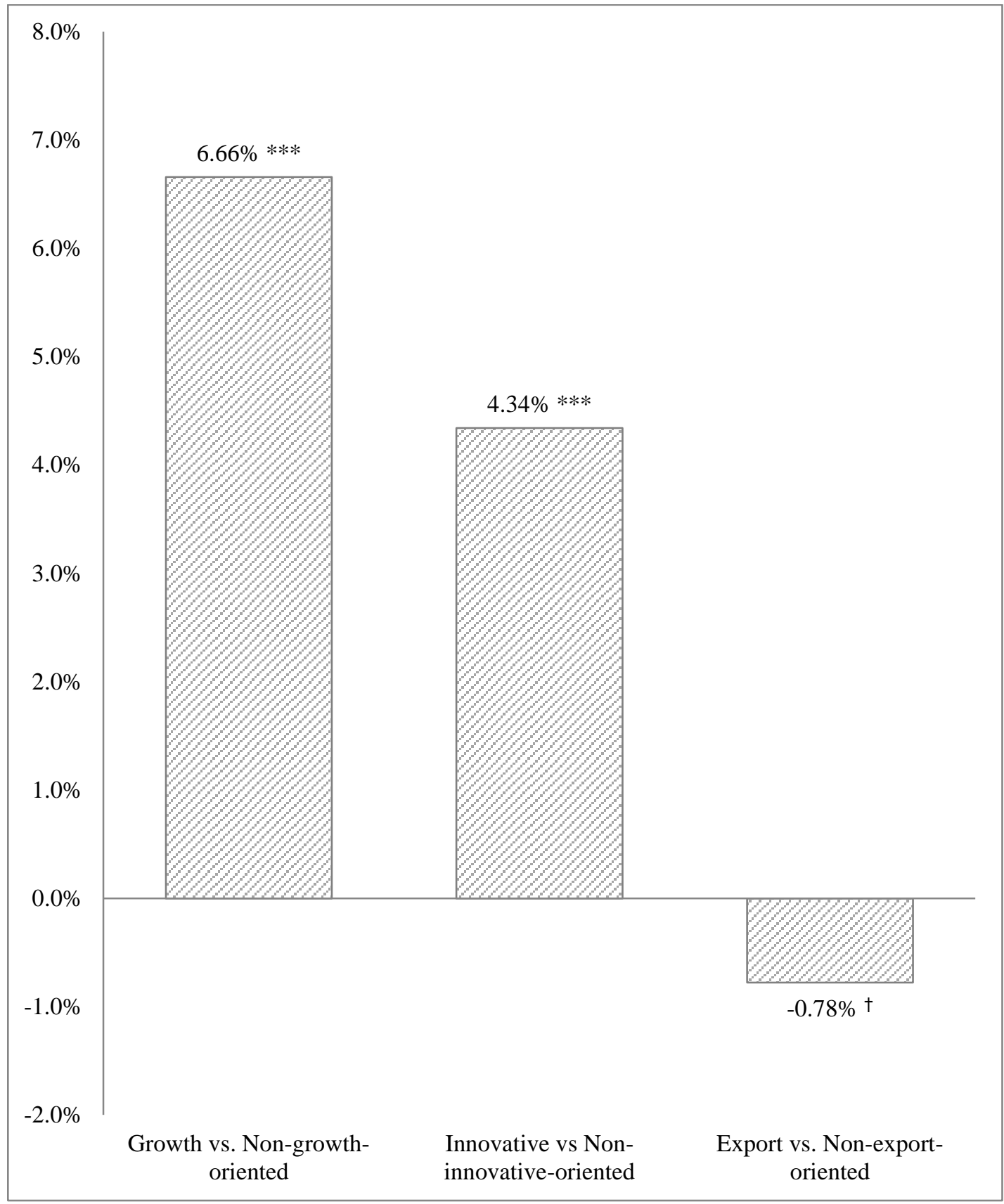

Notes: This Figure shows estimates of the differences in predicted probabilities applying for new finance among SMEs using credit cards by business orientation. $* * *, * * *, * *$ and $*$ refer to the significant level of $1 \%, 5 \%$ and $10 \%$, respectively. $†$ refer to not statistically significant results. 